\title{
Physico-Chemical Studies on Maroon Coloured Karonda (Carissa carandus) Collected from Uttar Pradesh, India
}

\author{
Vijay Singh Meena ${ }^{1 *}$, Bhanu Pratap ${ }^{2}$, K. C. Bhatt ${ }^{1}$, K. Pradeep ${ }^{1}$, N. L. Meena ${ }^{1}$, Ashok Kumar ${ }^{1}$ and Kuldeep Singh ${ }^{1}$ \\ ${ }^{1}$ Indian Council of Agricultural Research-NBPGR, New Delhi (110 012), India \\ ${ }^{2}$ Acharya Narendra Deva University of Agriculture and Technology, Kumarganj, Ayodhya, Faizabad, Uttar Pradesh (224 229), India
}

Corresponding Author

Vijay Singh Meena

e-mail:vjy_meena@yahoo.com

\author{
Article History \\ Article ID: IJEP0358 \\ Received in $07^{\text {th }}$ January, 2020 \\ Received in revised form $21^{\text {st }}$ January, 2020 \\ Accepted in final form $30^{\text {th }}$ January, 2020
}

\begin{abstract}
An exploration was conducted to collect genetic variability of Karonda (Carissa carandus), in different district of Uttar Pradesh during 2019-20. Augmenting germplasm is the first and the foremost activity indeed required for this fruit crop improvement as vast diversity still present in different ecosystem. Being a rich source of iron and minerals, it has potential to improve socio economic status and nutrition standard of Indian rural population. All genotype from IC632668 to 0632678 collected from different places of Uttar Pradesh found erect in nature with fruit diameter of 11 to $19 \mathrm{~mm}$ and with three distinct colours (white, green and red). Higher variation was reported in fruit weight, leave size, fruit colour, TSS, acidity and vitamin C content. Significant difference among TSS and vitamin C content was recorded. Attractive colour with good fruit size was observed in Accession no. IC-0632675 collected from Chiraigaon district Varanasi with excellent blend of TSS $\left(9.5^{\circ} \mathrm{B}\right)$, acidity $(1.10)$ and vitamin C $\left(28 \mathrm{mg} 100 \mathrm{~g}^{-1}\right)$.
\end{abstract}

Keywords: Biochemical, Karonda, landrace, maroon colour

\section{Introduction}

Primitive man ate all types of fruits, leaves, roots and tubers of plants collected from wild; before he learnt to grow plants. Many wild edible plants are nutritionally rich and supplement nutritional requirements of human and livestock, especially the vitamins and micronutrients. Underutilized plant species have great potential for contribution to food security, health (nutritional and/or medicinal), income generation and environmental services, but these have remained underexploited (Arora, 2014). The Karonda (Carissa carandas $L$., $2 n=22$ ), belongs to the family apocynaceae is a hardy, evergreen, spiny and indigenous shrub grown in India (Patil et al., 2017, Kirtikar and Basu, 2003, Deepika et al., 2016). There are about 25 species of genus Carissa, out of which five species have originated in India (Carissa carandas L, Carissa spinarum L, Carissa congesta, Carissa edulis and Carissa grandiflora). Carissa species has much socio economic importance in tribal area of India (Malik et al., 2010). It is well grown Rajasthan, Madhya Pradesh, Uttar Pradesh, Bihar, West Bengal, Maharashtra and in the Western Ghats. In Maharashtra, the major area under this crop is scattered in sub mountain area like Kolhapur, Ratnagiri and Pune district (Sawant et al., 2002). Being very hardy, it can be easily grown from arid to sub tropics and tropics climatic condition. As it is not specific a rained crop, the plant hardly needs any care and gives yield with the minimum management. It is a sprawling semi vine shrub native to India. Karonda is a fruit of dry areas containing fair amount of vitamin $\mathrm{C}$ and minerals (Athani et al., 2005). The Karonda fruit is an astringent, antiscorbutic and as a remedy for biliousness and useful for cure of anaemia (Wani et al., 2013, Tewari and Bajpai, 2008). A great beauty of plant is that its leaves are shining and ornamental and it bears flowers and fruits almost throughout the year (Banik et al., 2012). The sweeter fruits of Karonda may be eaten raw but the more acid ones are best stewed with plenty of sugar. The ripe fruits contains high amount of pectin (Rai and Misra, 2005). Therefore, it is also used in making jelly, jam, squash, syrup, tarts and chutney, which are of great demand in international market. The fruits, leaves and bark are rich in tannins (Morton, 1987). The fruits have anti-microbial and antifungal properties and its juice used to clean old wounds which have become infected. The fruit have an analgesic action as well as an antiinflammatory one (Das et al., 2013). The root extracts are used in lumbago, chest complaints and venereal diseases. In Ayurveda, the unripe fruits are used as astringent, appetizer, antipyretic, antidiabetic (Iyer and Dubhash, 2006; Itankar et al., 2011). The juice can be applied to the skin to relieve any 
skin problems. The roots are anthelmintic, stomachic and antiscorbutic and are useful in stomach disorders, intestinal worms, scabies and pruritus (Balakrishnan and Bhaskar, 2009; Gowda et al., 2011). Decoction of its leaves is also used against fever, diarrhoea and ear ache, and the roots are used for stomachic, vermifuge, remedy for itches, and insect repellent (Singh and Uppal, 2015). Leaf extract is externally applied for curing leprosy. Two drops of plant oil is given with half cup of honey for controlling worms of minors (Trivedi, 2007). Fruits are generally harvested at immature stage for vegetable purpose, fullyripen fruits are consumed fresh or processed. The unripe fruits yield milky white latex which can be used in preparing chewing gum and rubber (Kumar et al., 2007). Improvement in productivity will definitely boost the crop expansion in non-traditional areas of India and other ancillary industries. Fruits are also used to treat liver dysfunction andear ache. One of the simple approaches to improve production of any crop is to boost up productivity through utilization of existing genetic resource. A large germplasm resource is always favoured in plant breeding program as many desirable traits may obviously remain in the population, which may exploit breeding program.

The diversity of Karonda has not appropriately collected and used for breeding programmes hence this fruit remain poor yielder and underutilized. Proper documentation of the germplasm can assist in breeding to improve its yield related aspects. Plant breeding programs depend on the efficient selection of parental genotypes. In this regard, the analysis of genetic diversity and relatedness among genotypes becomes very useful. The present study was undertaken to demonstrate the usefulness of morphological, biochemical traits for studying the variability among a diverse collection of Karonda collected from different part of Uttar Pradesh, India.

\section{Materials and Methods}

Eleven genotypes of Karonda were collected from 25.18 to $26.47 \mathrm{~N}$ latitude, 80.40 to $83.4 \mathrm{E}$ longitudes and an altitude of 20 to 126.8 meter of UP (India) and subjected for physicochemical analysis during 2019-20. Morphological traits (both quantitative and qualitative) for assessment of diversity of fruit size and biochemical attributes were studied using Completely Randomised Block Design (CRD). Twenty mature fruits were selected randomly from each accession to record observation on morphological and biochemical parameters. Fruit size (length and girth) was measured with the help of digital vernier calliper, while fruit weight was taken by digital balance. The total soluble solids (TSS) were determined with Erma Hand Refractometer ( $\left.0-32^{\circ} \mathrm{Brix}\right)$. The titratable acidity (\%) and ascorbic acid content (mg $100 \mathrm{~g}^{-1}$ ) were determined by AOAC (1960) methods. The differences in the means of each agronomic trait between accession were compared using ANOVA (analysis of variance), while mean values were used for analysis of variance.

\section{Results and Discussion}

All genotype from IC632668 to 0632678 from different places of Uttar Pradesh (Table 1) belonging to Carissa carandus were found erect, tall (14-6 meter), with milky latex secretion on harvesting, spiny (2.0-3 cm length); leaves were green, simple and opposite; fruits were white, pink and maroon coloured. It is clear from Table 2 that remarkable diversity was present on morphological and biochemical attributes like fruit size (oblong and round), fruit length (14 to $23.9 \mathrm{~mm}$ ), fruit diameter (11 to $19 \mathrm{~mm}$ ), fruit weight (4 to $11.3 \mathrm{~g}$ ), leave length ( 37 to $58 \mathrm{~mm}$ ), fruit pulp colour, flower fragrance (mild to strong), pulp colour (white, pink, red and dark red), seed

\begin{tabular}{|c|c|c|c|c|c|c|c|c|c|c|c|}
\hline $\begin{array}{l}\text { SI. } \\
\text { No. }\end{array}$ & IC. No. & Source & Frequency & Sample type & $\begin{array}{l}\text { Sam. } \\
\text { method }\end{array}$ & Habitat & District & State & Lat. & Long. & Alt. \\
\hline 1. & 632668 & Natural wild & Occasional & Invidual plant & Selective & Disturbed & $\begin{array}{l}\text { Luc- } \\
\text { know }\end{array}$ & UP & 27 & 80.44 & 53.3 \\
\hline 2. & 632669 & Farmer's field & Occasional & Invidual plant & Selective & Cultivated & $\begin{array}{l}\text { Luc- } \\
\text { know }\end{array}$ & UP & 27 & 80.4 & 64 \\
\hline 3. & 632670 & Farmer's field & Frequent & Invidual plant & Selective & Cultivated & Jaunpur & UP & 25.46 & 82.34 & 66 \\
\hline 4. & 632671 & Farmer's field & Frequent & Invidual plant & Selective & Cultivated & Jaunpur & UP & 25.45 & 82.36 & 71.3 \\
\hline 5. & 632672 & Farmer's field & Frequent & Invidual plant & Selective & Cultivated & Jaunpur & UP & 25.44 & 82.35 & 70.1 \\
\hline 6. & 632673 & Farmer's field & Abundant & Invidual plant & Selective & Cultivated & Varanasi & UP & 25.21 & 83.4 & 17.1 \\
\hline 7. & 632674 & Farmer's field & Rare & Invidual plant & Selective & Cultivated & Varanasi & UP & 25.21 & 83.4 & 17 \\
\hline 8. & 632675 & Farmer's field & Rare & Individual plant & Selective & Disturbed & Varanasi & UP & 25.18 & 82.9 & 65 \\
\hline 9. & 632676 & Farmer's field & Abundant & Individual plant & Selective & Cultivated & Varanasi & UP & 25.21 & 83.4 & 20 \\
\hline 10. & 632677 & Natural wild & Occasional & Individual plant & Wild & Disturbed & Ayodhya & UP & 26.32 & 81.18 & 126.8 \\
\hline 11. & 632678 & Natural wild & Occasional & Individual plant & Wild & Disturbed & Ayodhya & UP & 26.32 & 81.49 & 126.8 \\
\hline
\end{tabular}




\begin{tabular}{|c|c|c|c|c|c|c|c|c|c|}
\hline IC. No. & $\begin{array}{l}\text { Fruit } \\
\text { weight } \\
\text { (gm) }\end{array}$ & $\begin{array}{l}\text { Fruit length } \\
\qquad(\mathrm{mm})\end{array}$ & $\begin{array}{c}\text { Fruit } \\
\text { diameter } \\
(\mathrm{mm})\end{array}$ & $\begin{array}{l}\text { Seed } \\
\text { weight } \\
\text { (g) }\end{array}$ & $\begin{array}{l}\text { Leaf } \\
\text { length } \\
(\mathrm{mm})\end{array}$ & $\begin{array}{l}\text { No. of } \\
\text { Seed } \\
\text { fruit }^{-1}\end{array}$ & $\begin{array}{l}\text { TSS } \\
\left({ }^{\circ} \mathrm{B}\right)\end{array}$ & $\begin{array}{c}\text { Acidity } \\
(\%)\end{array}$ & 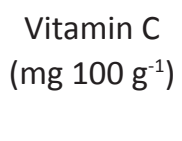 \\
\hline 632668 & 4.0 & 14.7 & 12.3 & 10.33 & 37.0 & 6 & 3.7 & 0.90 & 14.3 \\
\hline 632669 & 8.0 & 16.7 & 13.0 & 12.56 & 39.0 & 5 & 3.0 & 1.10 & 18.0 \\
\hline 632670 & 11.0 & 23.7 & 14.7 & 16.44 & 56.0 & 4 & 4.7 & 1.73 & 22.3 \\
\hline 632671 & 11.3 & 15.7 & 14.0 & 13.67 & 50.0 & 4 & 5.5 & 1.30 & 12.7 \\
\hline 632672 & 11.0 & 14.0 & 13.3 & 12.78 & 44.0 & 5 & 6.0 & 1.37 & 12.0 \\
\hline 632673 & 7.0 & 14.7 & 12.7 & 11.44 & 48.0 & 6 & 8.5 & 1.27 & 14.3 \\
\hline 632674 & 5.3 & 17.3 & 14.7 & 12.42 & 57.0 & 3 & 5.0 & 1.00 & 12.0 \\
\hline 632675 & 10 & 17.0 & 19.0 & 14.78 & 48.7 & 3 & 9.5 & 1.10 & 28.0 \\
\hline 632676 & 7.3 & 20.5 & 12.0 & 13.27 & 48.0 & 5 & 5.3 & 1.13 & 8.7 \\
\hline 632677 & 10.7 & 15.5 & 13.0 & 13.06 & 47.7 & 6 & 6.8 & 1.60 & 10.3 \\
\hline 632678 & 8.3 & 16.0 & 11 & 11.78 & 41.3 & 6 & 4.4 & 1.43 & 10.3 \\
\hline SEm \pm & 0.5 & 0.7 & 0.79 & NS & 1.15 & NS & 0.38 & 0.38 & 0.6 \\
\hline $\mathrm{CD}(p=0.05)$ & 1.4 & 2.1 & 2.3 & NS & 3.4 & NS & 1.1 & 1.10 & 1.8 \\
\hline $\mathrm{CV}$ & 9.6 & 7.3 & 9.86 & NS & 4.25 & NS & 11.56 & 11.33 & 7.0 \\
\hline
\end{tabular}

colour (white and black), number of seeds fruit ${ }^{-1}$ ( 3 to 7 ), TSS ( 3 to $9.5^{\circ}$ B), acidity (0.9 to1.73) and vitamin C ( 8.7 to $28 \mathrm{mg}$ $100 \mathrm{~g}^{-1}$ ) content.

People's perception towards food items is generally influenced by their appearance. Generally colour is an important component of appearance, which governs the quality of foods. Fruits with accession number IC-0632675 collected from Chiraigaon district Varanasi located at 25.21 latitude and 83.4 longitudes were unique, superior and attractive maroon coloured. Fruit weight was higher $(10 \mathrm{~g})$ with less no. of seeds fruit ${ }^{-1}(3)$ with excellent blend of TSS $\left(9.5^{\circ} \mathrm{B}\right)$ and acidity (1.10). Higher vitamin C (28 mg $\left.100 \mathrm{~g}^{-1}\right)$ content was also recorded in these fruits (Table 2 and Figure 1).

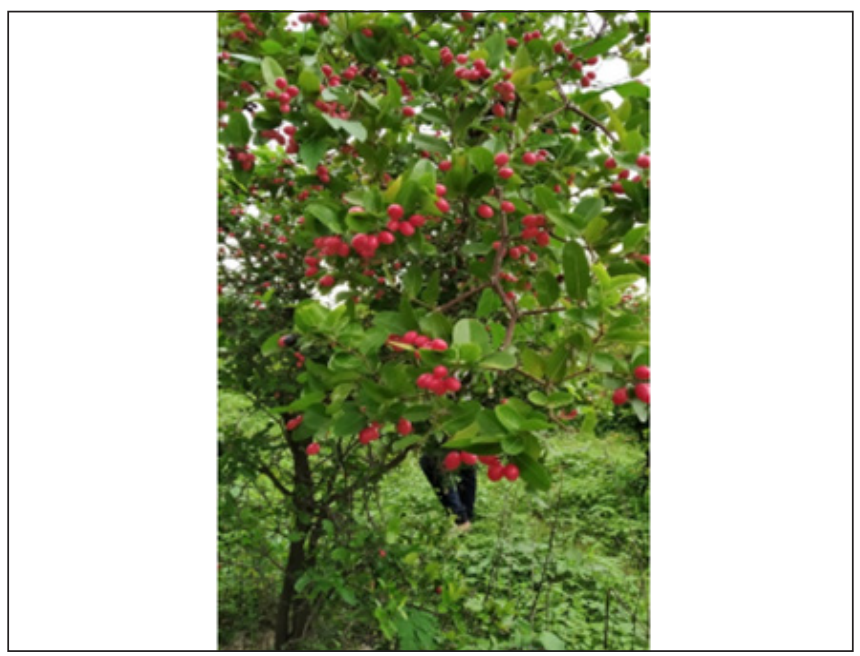

Figure 1: Promising accession IC-0632675 of karonda with attractive maroon coloured fruits

\section{Conclusion}

Morphological and biochemical categorization of karonda accessions into different groups provided important information. Accession no. IC-0632675 collected from Chiraigaon district Varanasi was found unique and superior in term of fruit colour (attractive maroon), fruit weight (10 g), number of seeds $\left(3\right.$ fruit $\left.^{-1}\right)$, TSS $\left(9.5^{\circ} \mathrm{B}\right)$, acidity (1.10) and vitamin C (28 mg $\left.100 \mathrm{~g}^{-1}\right)$. This work will help karonda breeders for further improvement through conventional and non-conventional breeding approaches.

\section{Acknowledgment}

The authors are thankful to Dr. Kuldeep Singh, Director, ICAR-NBPGR, New Delhi and Dr S.P. Ahlawat, Head, (DPEGC) for providing necessary facilities for conducting exploration on karonda.

\section{References}

AOAC, 1960. Official methods of analysis, $14^{\text {th }}$ ed. Association of official chemist. Washington D.C.,

Arora, R.K., 2014. Diversity in Underutilized Plant Species - An Asia Pacific Perspective. Bioversity International, New Delhi, India, 203.

Athani, S.I., Patil, B.R., Swamy, G.S., Patil, P.B., Kanamadi, V., Shirol, A.M., Dinakara, A.J., 2005. Genetic variability in Karonda (Carissa carandas L.) for physico-chemical characters of fruit. The Asian Journal of Horticulture 2, 1-3.

Balakrishnan, N., Bhaskar, V.H., 2009. Karonda (Carissa carandas Linn.) as a phytomedicine: a review. The 
Pharma Review 9, 95-100.

Banik, B.C., Ghosh, S.N., Singh, S.R., 2012. Research and development in Karonda, a semi wild fruit in India. Acta Horticulturae 94, 61-69.

Das, S.C., Prakashm, J., Deb, A.K., Biswas, T., 2013. Medicinal value of underutilized fruits in hilly Tripura. Acta Horticulturae 972, 135-41.

Deepika, S., Misra, K.K., Rai, R., 2016. Studies on suitability of cultivars, picking dates and drying methods for the preparation of karonda (Carissa carandus L.) fruit powder. Indian Journal of Horticulture 73, 267-273.

Gowda, V.N., Smitha, M.N., Reddy, P.K., 2011. Studies on seed viability, germination and seedling growth of minor fruit plants. Acta Horticulturae 890, 135-38.

Itankar, P.R., Lokhande, P.J., Verma, P.R., Arora, S.K., Sahu, R.A. Patil, A.T., 2011. Antidiabetic potential of unripe Carrisa carandas Linn. fruit extract. Journal of Ethnopharmacology 135, 430-3.

Iyer, C.M., Dubhash, P.J., 2006. Anthocyanin of Karwand (Carrisa carandus) and studies on its stability in model systems. Journal of Food Science and Technology 30, 246-8.

Kirtikar, K.R., Basu, B.D., 2003. Indian Medicinal Plants. Lalit Mohan Basu, Allahabad.

Kumar, D., Pandey, V., Nath, V., 2007. Karonda (Carissa congesta) an underutilized fruit crop. In: Peter, K.V., Underutilized and underexploited Horticultural Crops. New India publishing agency, 313-25.

Malik, S.K., Chaudhury, R., Dhariwal, O.P., Bhandari, D.C., 2010. Genetic Resources of Tropical Underutilized Fruits in India. NBPGR, New Delhi, 168.
Morton, J.F., 1987. Carissa carandas. In: Morton, J.F., Miami, F.L. (Eds.), Fruits of Warm Climates, 422-424.

Patil, U.S., Athani, S.I., Naik, N.H., Jagadeesh, R.C., Allolli, T.B., Gopali, J.B., 2017.

Quality and yield characterization of Karonda. International Journal of Pure and Applied Bioscience 5, 374-378.

Rai, R., Misra, K.K. 2005. Micropropagation of karonda (Carissa carandas) through shootmultiplication. Scientia Horticulture 103, 227-232.

Sawant, B.R., Desai, U.T., Ranpise, S.A., More, T.A., Sawant, S.V., 2002. Genotypic and Phenotypic variability in Karonda (Carissa carandas L.). Journal of Maharashtra Agricultural Universities 27, 266-268.

Singh, A., Uppal, G.K., 2015. A review on Carissa carandus Phytochemistry, Ethno-pharmacology and Micropropagation as conservation strategy. Asian Journal of Pharmaceutical and Clinical Research 8, 26-30

Tewari, R.K., Bajpai, C.K., 2008. Studies on seed germination and seedling growth of Lasodha in Bundelkhand region. Journal of Tropical Forestry 24, 47-49.

Trivedi, P.C., 2017. Ethanomedicinal plants of India Aavishkar publishers, Churna Rasta Jaipur (Rajasthan) India, 71.

Wani, R.A., Prasad, V.M., Hakeem, S.A., Sheema, S., Angchuk, S., Dixit, A., 2013. Shelf life of Karonda jams (Carissa carandas L.) under ambient temperature. African Journal of Agricultural Research 8, 2447-2449. 